\title{
An Open Letter to President Carter About Indochina Refugees
}

The Hon. Jimmy Carter

President of the United States of America

The White House

W'ashington, D.C.

Dear Mr. President:

The United States has been most generous in its efforts to help rescue and find homes for the Vietnamese refugees. Without this help I do not know where hundreds of thousands of refugees, including myself, would be today. We avail ourselves of this opportunity to express to you and to the American people our deep gratitude for the hospitality, care, and assistance you continue to give us.

I feel embarrassed because four years after the end of U.S. involvement in Vietnam the Vietnamese continue to be a problem and a burden for the USA; we still look to you for help. I hope you will forgive us because you know that we the ordinary people have always been helpless; there was very little we could do to influence the course of events that afflicted our country and our lives and finally drove us out of our homeland.

As you well know, the refugee situation in Southeast Asia is desperate and cries out for a new approach. The old approach was based upon the assumption that the exodus of the "misfits" would subside with time and would soon come to an end.

Today, almost four years after the end of the war, the outflow of refugees has not diminished; it has instead increased tenfold during the past year despite a particularly stormy season and the thousands who died at sea from thirst, hunger, or drowning. People are leaving in increasingly large numbers because Communist officials are selling "escape visas" to the ethnic Chinese and other refugees who can afford the price. They are also leaving because of widespread hunger, harsher political repression, regimentation, suppression of human rights, inefficient control of the costs, and corruption at all levels. Finally, because of universal conscription of young men and women for the war against Cambodia and China, a sense of despair and hopelessness prevails among the Southern people.

People had hoped that the end of the war would bring peace, reconciliation, and an end or at least an abatement of the major social ills that plagued the old society; among those were corruption, black market, unemployment, a privileged class, foreign dependency, foreign bases, etc. The reality is the opposite. Most of the ills have not diminished; some are worse now than ever before; such is the case with corruption, black market, unemployment. Besides the old calamity of war there is the new calamity of starvation and of vindictive repression of the southern people.

In fact, in four years the North Vietnamese have turned the South into such a place of hell that everybody wants to leave. Rather die at sea than living under Communist rule. An estimated 50 per cent of those who set out to escape never make it.

In recent months "boat people" are arriving in Malaysia at the rate of 600 per day. Some 441 refugees drowned off the coast of Malaysia when their boats capsized after having been refused landing by Malaysian police. One must recall that the Malaysians have been hospitable at first, but waves after waves of refugees inundating their shores have turned them hostile.

We do not believe that the Indochinese refugees are a Malaysian, a Thai, or a U.S. problem. It is an international problem, a human problem. The responsibility to bring assistance to people in distress rests on the shoulders of the human community as a whole. Because of past involvement and a hospitable tradition, the U.S. should take the lead in efforts to help rescue and find homes for the refugees. It is also the responsibility of men and women of good will and compassion around the world to give help to fellowmen in grave danger for their lives.

In this respect the French set out a good example. A project called "Un Bateau pour le Vietnam" (A Ship for Vietnam) sponsored by prominent Frenchmen, among those are philosopher Jean Paul Sartre and actress Brigitte Bardot, will set sail to the South China Sea to pick up refugees. Another group called "Bridge of Freedom" plans to launch ten small rescue boats based in West Malaysia. The group is based in Huntington Beach, California, and plans to raise money from Vietnamese refugees to help rescue the boat people. But once loaded with refugees, the French compassionate ship and the Bridge of Freedom boats will not know where to unload the refugees in order to go back to sea to rescue more. Two earlier projects, one undertaken by 
the World Council on Religion \& Peace in conjunction with a Paris-based Vietnamese Buddhist group and another by World Vision, encountered the same difficulties. The Citizen Commission on Indochina Refugees has told Secretary of State Cyrus R. Vance that a human disaster is imminent unless free nations undertake a massive resettlement effort to relieve first asylum countries of their intolerable burden. The number of refugees will reach the million this year and may continue at the present rate for several years. Some refugees have been waiting in the camps for eighteen months. Thailand and Malaysia may close their doors and return the refugees to the ocean or to their countries. "Boat people" sometimes feel that their lives are not worth more than that of ants and worms.

Dear Mr. President, may we suggest that the U.S. and the free nations explore the possibilities of providing the refugees with a piece of land. It can be an island or a certain acreage of land in Southeast Asia or the Pacific. It will serve as a landing center, a processing area for those to be resettled in other countries, and for a number of refugees a permanent home.

The place will receive refugees picked up by passing ships or who will have reached by boat the shores of a Southeast Asian nation. It will also receive refugees now in camps or on boats near the shores. Self-sustaining communities can be developed in the new place. The money now used to buy foods for the refugees can be used to buy building materials and farm implements for the refugees to start earning a living from the land and the sea.

The establishment of the place will save thousands of lives, those who die dried up in their boats or "resettled" at the bottom of the sea because dozens of passing ships have ignored them. The ship captains will be more willing to rescue refugees once they know where to unload them. With such a place, Thai, Malaysian police will no longer push refugee boats back to sea because they will be assured that the refugees will be swiftly moved out of their countries.

The receiving center will permit a more orderly resettlement effort. The U.S., France, Canada, Australia...will no longer be obligated to take refugees on an emergency basis. There are 1.5 million Chinese the Vietnamese Government wants to get rid of. With the receiving center, countries providing permanent asylum can screen refugees for possible infiltration of Communist agents and other undesirable persons. Such a screening is made much more difficult with the rush and hustle of emergency situations. With a receiving center, the U.S. attorney general will not have to resort to his special parole authority every three months or so to meet emergency situations that may arise every month.

Southeast Asian nations, because of their proximity to Indochina, are being inundated with refugees. With a holding center under U.N. trusteeship the burden will be more equally shared among the assisting nations. State Department officials reported at the December 11 , 1978, Geneva meeting on refugees that it takes $\$ 1$ million to resettle 280 refugees in the U.S. This same $\$ 1$ million can resettle many more refugees in Southeast Asia. A number of refugees indicate that they wish to live near their homeland rather than in France, Canada, or the U.S. We also learned from the Washington Post $(1 / 3 / 79)$ that a congressional group led by Representative Lester Wolff has visited the Asian Development Bank during the Southeast Asia visit and that the bank has agreed to provide funds to set up "self-sustaining" refugee resettlements in Southeast Asia. The question of a holding center has also been discussed at the Geneva meeting. Our proposal is that the three kinds of centers be combined into one: a landing center, a processing center for those who qualify for other countries, and a permanent home for those who remain. The difficulty with our proposal lies in the fact that a number of refugees will remain permanently in the new territory, which may not be returned to its country. Like Hong Kong, Macao, it remains separate from its mainland country.

We understand the extreme difficulty involved in finding such a place. No nation or people will be willing to sell or donate land or otherwise make a piece of their land available to foreigners for a long period of time. Yet when we are confronted with today's situation, we have to attempt the impossible. It is our estimate that as many as two million refugees will get out of Vietnam in the next few years and it is unrealistic to assume that all those people will be resettled in the free nations. What will we do with all the refugees whose resettlement in industrialized societies is neither feasible nor desirable?

Resettlement in Southeast Asian countries where they are now is being considered. On that subject the refugees would like to convey to you their views. Like in other parts of Asia, corruption is rampant in Thailand and Malaysia. Funds provided those governments to create self-sustaining refugee communities on their soil will be siphoned off by local corruption and little will benefit the refugees. Moreover, friction may arise with the local population. Both corruption and friction already exist now around the refugee camps.

Understandably, it will not be easy to find such a piece of land. But there is no easy solution to the refugee problem. There is not even a good solution, but only solutions that on balance have less disadvantages than others, because they will leave less residual problems.

The country which will agree to provide the refugees with a piece of land will be hailed as the savior of the Vietnamese and will deserve our everlasting gratitude. By so doing, it will save hundreds of thousands of lives and alleviate much human sufferings. It will also help preserve the cultural heritage.

Mr. President, we humbly request that you ask Senator Richard Clark, the new ambassador for refugees, to visit the Southeast Asian nations to explore the possibilities of finding a piece of land.

Most respectfully submitted,

\section{Le Thi Anh}

From a letter of February 5, 1979, by Le Thi Anh to President Jimmy Carter. The writer is Editor of Vietnam News (Cheverly, Maryland). 